\title{
Physical-chemical and antimicrobial properties of Egg White Protein Powder films incorporated with orange essential oil on Kashar Cheese
}

\author{
Nazan KAVAS $^{1 *}$, Gökhan KAVAS²
}

\begin{abstract}
In this study, the effects of edible film $\left(\mathrm{EWPP}_{\mathrm{CVV}}\right)$ produced by the addition $(2 \% \mathrm{v} / \mathrm{v})$ orange essential oil $\left(\mathrm{EO}_{\mathrm{CVV}}\right)$ to sorbitol $(3 \% \mathrm{w} / \mathrm{v})$ egg white protein powder (EWPP) based film on the physico-chemical and antibacterial properties, appearance (color, structure, brightness) and odor of kashar cheese were studied .Cheese samples were separately coated with these films and stored at $+4^{\circ} \mathrm{C}$ for 30 days. Analyses were performed on the 1st, 7 th, 15 th and the 30th days of storage. During storage, the inner and outer hardness values during storage of the samples coated with $\mathrm{EWPP}_{\mathrm{CVV}}$ were lower than of those coated with EWPP. With the addition of $\mathrm{EO}_{\mathrm{CVV}}$ to the film, the antimicrobial effects on of the studied microorganisms increased. EWPP film was brighter and more transparent compared to $\mathrm{EWPP}_{\mathrm{CVv}}$. The color of EWPP $\mathrm{Cvv}_{\mathrm{Cas}}$ more yellowish.
\end{abstract}

Keywords: egg white protein powder; edible films; orange essential oil; kashar cheese.

Practical Application: Edible films containing essential oils provide new ways to enhance microbial safety and shelf-life of foods by direct and/or indirect contacts of the antimicrobials in the films with the food. The incorporation of essential oils into Egg White Protein Powder based edible film applied onto kashar cheese helps to reduce microbial load during storage. EWPP $\mathrm{CVV}_{\mathrm{C}}$ offer the potential for all natural antimicrobials for use in improving the safety of organic or all natural foods.

\section{Introduction}

Kashar cheese is a semi-hard type cheese traditionally produced from cow's milk. "Acidity development", "curd roll out" and "curd stretching" processes are performed in traditional production (Durlu-Ozkaya \& Gün, 2007; Ucuncu, 2004).

Chicken egg white is a perfect source of proteins, lipids, minerals and vitamins. Proteins in eggs are distributed among the egg white (EW) and the yolk. EW consists of water (88\%), protein $(11 \%)$ and trace amounts (1\%) of carbohydrates, lipids and ash (Kovacs-Nolan et al., 2005). These proteins are recognized by their functional properties such as nutrition (Abeyrathne et al., 2013; Ko \& Ahn, 2008), health (KovacsNolan et al., 2005) and antimicrobial effects. The antimicrobial and antiviral effects of EWP are associated with its protein content, in particular lysozyme which is registered for use as a preservative in some foods by WHO and is referred to as a "bacteriolytic protein" (Banwart, 1983; Kovacs-Nolan et al., 2005). EWP can be hydrolyzed by various enzymes (pepsin, trypsin and $\alpha$-chymotrypsin) in different conditions. These hydrolyzed products are defined as functional (bioactive) peptides which have proven beneficial (Kovacs-Nolan et al., 2005 and antimicrobial effects (Abeyrathne et al., 2013). Egg white protein powder (EWPP) is produced by drying EWP by conventional spray methods (Masters, 1991).

Edible films are derived from polysaccharides, proteins or lipids. These films are edible thin polymer layers that form gas and water barriers in foods. Films are generally produced using biological hydrophilic materials including protein, starch, pectin, cellulose, alginates and karregen (Taqi et al., 2011). Sorbitol is prominent among the plasticizers due to its lower moisture absorption and $100 \%$ dissolution capabilities ( Ressouany et al., 1998). With the addition of different essential oils to protein based films, composite films with good mechanical, oxygen and especially water barrier properties are obtained (Avena-Bustillos \& Krochta, 1993; Mchugh \& Krochta ,1994; Shellhammer \& Krochta, 1997). Similar results are also obtained in EWP based films (Yuno-Ohta et al., 1996). It has been reported that the properties of egg albumin based films are similar to those of protein based films. Egg albumin based films are also reported to be brighter and more transparent compared to soy protein, gluten and corn based films. Edible films are also used as a carrier matrix for antimicrobial and antioxidant agents (Bourtoom, 2008; Krochta, 1997). Essential oils (EO), which have gained attention in recent years due to their antimicrobial activities, are frequently used to control the growth of pathogenic bacteria and prevent degradation in foods (Burt, 2004; Padgett et al., 1998; Zivanovic et al., 2005). EO show antimicrobial activity against bacteria, yeasts and molds that cause spoilage in foods due to the active substances in its content . In edible film systems, an antimicrobial agent slowly passes from the film layer to the food and thus a high concentration of antimicrobial agent remains in the film and at the surface of the food, providing a longer effect against microorganisms (Coma et al., 2002). 
Citrus genus (Rutaceae) EO have antibacterial, antifungal, antioxidant, anticancer, anti-inflammatory and hypoglycemic effects (Ladaniya, 2008). Antimicrobial effects have been demonstrated against Escherichia coli, E. coli O157:H7, Salmonella typhimurium, Listeria monocytogenes, Vibrio vulnificus (Kim et al., 1995a) and S. typhimurium (Kim et al., 1995b). It was determined that lemon, orange and bergamot essential oils have bactericidal effects against Campylobacter jejuni, E. coli O157:H7, L. monocytogenes, Bacillus cereus, Staphylococcus aureus (Fisher \& Phillips, 2006). The antifungal effects of Citrus genus EO has determined against Penicillium digitatum, Penicillium italicum (Caccioni et al., 1998) and Saccaromyces cerevisiae (Belletti et al., 2004). Orange (Citrus sinensis [L.] Osbeck) (C.sinensis) EO, which is found in the rind or peel, contains antimicrobial bioactive components including coumarins, flavonoids (flavone, flavanone to the flavonols), carotenoids, terpenes and linalool (Gupta et al., 2014). Orange EO consists of limonene (90\%), which is basically a sesquiterpene, and also contains sabinen, myrcene, linalyl acetate, linalool, citronellal, citronellol, neral and geranial (Hamdan et al., 2013). The composition of EOs vary depending on the orange cultivar (Hamdan et al., 2013). There are different studies available on the antimicrobial effects of orange cultivars under laboratory conditions and in foods. However, there are no previous studies in literature on the essential oil of the orange cultivar used in this study (C. sinensis [L.] Osbeck var. valencia) and its antimicrobial effect in EWPP based edible films. This cultivar is suitable for storage and transportation, is rich in aroma and has few seeds. Therefore, it is suitable in terms of both being edible and for use in industry. It is an orange cultivar which adapts well to different ecological conditions and is resistant to cold and desert climates; it is cultivated currently in the Mediterranean Region of Turkey .

In this study, edible film (EWPP) was produced by adding $3 \%(\mathrm{w} / \mathrm{v})$ sorbitol (S) to EWPP. This film was seperated in two parts, one of which was fortified with $\mathrm{EO}_{\mathrm{CVV}}[2 \%(\mathrm{v} / \mathrm{v})]$ obtained from orange (C. sinensis [L.] Osbeck var. Valencia) rind, yielding EWPP $_{\mathrm{CVV}}$ based film. A group of kashar cheese samples was coated with this film, a second group was coated only with EWPP, and a third group of cheese samples was left uncoated (control (K) sample). All of the cheese samples were artificially contaminated with Escherichiae coli O157:H7 (E.coli O157:H7), Listeria monocytogenes (L.monocytogenes) and Staphylococcus aureus (S.aureus) at $10^{6} \mathrm{Log} 10 \mathrm{cfu} / \mathrm{g}$ and stored at $4^{\circ} \mathrm{C}$. The samples were analyzed in terms of microbiological and physico-chemical properties, appearance (color, structure, brightness) and odor. Egg White Protein Powder based edible films against selected cheese associated bacteria and to determine effectiveness of this essential oil incorporated films on microbiological characteristics of kashar cheese during refrigerated storage.

\section{Materials and methods}

\subsection{Egg White Protein Powder (EWPP) and D-Sorbitol}

Alfasol $^{\circledR}$ egg white protein powder (EWPP) (pH 7.00, total microorganisms $<100 \mathrm{cfu} / \mathrm{g}$, coliform $<10 \mathrm{cfu} / \mathrm{g}$, no $S$. aureus or Salmonella content and $7.10 \%$ humidity) was obtained from Kimbiotek Chemical Agents, Inc. (İstanbul, Türkiye) and D-sorbitol (S1876) was obtained from Sigma-Aldrich.

\subsection{Essential oils}

Which is obtained from orange (C. sinensis [L.] Osbeck var. valencia) fruit peels the essential oils $\left(\mathrm{EO}_{\mathrm{CVv}}\right)$ investigated in this work were purchased from flora Hatay (Turkey). Esential oil was obtained by hydro-destillation for $3 \mathrm{~h}$ using a Clevenger-type apparatus (Bounatirou et al., 2007; Gupta et al., 2014).

\subsection{Analysis of essential oils and volatile compounds by GC}

The oils used were those of $C$. sinensis L. (Osbeck) var. valencia, and the active components (limonen, sabinen, mirsen, p-simen, linalol etc.) were obtained from Sigma-Aldrich (Steinheim, Germany). GC analyses were carried out on a Shimadzu GC-9A gas chromatograph equipped with Thermon-600 T $(30 \mathrm{~m} \times 0.25 \mathrm{~mm} \times 0.25 \mu \mathrm{m}$ film thickness $)$. The oven temperature was programmed at $15-200^{\circ} \mathrm{C} / \mathrm{min}$ for the total of 15 minutes. Other operating conditions were: carrier gas, nitrogen with a flow rate of $10.0 \mathrm{~mL} / \mathrm{min}$; injector and detector temperatures were $250{ }^{\circ} \mathrm{C}$ and $300{ }^{\circ} \mathrm{C}$, respectively; split ratio 1:20; column pressure $56.8 \mathrm{hPa}$.

\subsection{Kashar cheese}

The whole-fat traditional semi-hard kashar cheese samples were produced by traditional methods with cow's milk (protein $3.5 \mathrm{~g} / 100 \mathrm{~g}$, carbohydrates $2.4 \mathrm{~g} / 100 \mathrm{~g}$ ). This milk was pasteurized at $60{ }^{\circ} \mathrm{C}$ for 30 minutes, cooled to $34^{\circ} \mathrm{C}$ and $0.02 \% \mathrm{CaCl}_{2}$ added. At this temperature double strength rennet extract was used as the clotting agent. The curds were milled at pH 5.4 and then heated for $10-15$ minutes at $39^{\circ} \mathrm{C}$ .The mild curds were then salted with $\mathrm{NaCl}(400 \mathrm{~g} / 40 \mathrm{~kg})$ and at $\mathrm{pH}$ 5.10. The curds were heated in using indirect steam injection at $85-90{ }^{\circ} \mathrm{C}$ for 15 minutes. The hot product was pressed at ambient temperature. Finally, it was divided into 3 pieces of cheese in $100 \mathrm{~g}$ quantities. All cheeses were stored at $5 \pm 1{ }^{\circ} \mathrm{C}$ for 30 days.

\subsection{Preparation of edible film solution}

Edible films were prepared according to Pintado et al. (2010) and Mchugh \& Krochta (1994), with some modifications. Accordingly, 5\% w/v EWPP was prepared, and after the addition of $\% 3 \mathrm{w} / \mathrm{v}$ sorbitol to the solution, a homogenization process was carried out in a homogenizer. The mixture $\mathrm{pH}$ was adjusted to 8 and kept in a water bath at $45 \pm 2{ }^{\circ} \mathrm{C}$ for 30 minutes in order to improve the mechanical properties of the film solution and protect to coagulation of EWPP. The solution was then cooled to room temperature and sorbitol-amended EWPP was obtained. The cooled film was filtered and divided into 3 equal parts; 1 part was coated edible film only EWPP, 2 part was contain $2 \%(\mathrm{v} / \mathrm{v}) \mathrm{EO}_{\mathrm{CVV}}\left(\mathrm{EWPP}_{\mathrm{CVV}}\right)$, and the third part $(\mathrm{K})$ was applied to artificial contamination which was uncoated edible film.

Following the orange essential oil addition, in order to maintain the homogeneous distribution of oil in the solution, Tween $20(0.5 \%(\mathrm{v} / \mathrm{v})$ was added (Zivanovic et al., 2005) and the solution was centrifuged again at 20,000 rpm for 1 minute (3-16 K Type-Model, Sigma, Germany). As a result, edible 
film containing EWPP based \% 2(v/v) $\mathrm{EO}_{\mathrm{CVV}}\left(\mathrm{EWPP}_{\mathrm{CVV}}\right)$ were obtained. Cheese samples coated with these films were left to dry at room temperature for 24 hours.

\subsection{Preparation and storage of samples}

E. coli O157:H7 (ATCC 43895), L. monocytogenes (ATCC 19118) and S. aureus (ATCC 6538) strains used for the artificial contamination of kashar cheese samples were obtained from Hemakim Corporation (Turkey). $10^{6} \mathrm{cfu} / \mathrm{g}$ inocula were used for the artificial contamination. $100 \mathrm{~g}$ traditional semi-hard kashar cheese samples placed in sterile containers were contaminated with $0.1 \mathrm{~mL}$ inocula spread across the surface of the samples with the help of a drigalski spatula. Contaminated samples were kept at $+4{ }^{\circ} \mathrm{C}$ for 15 minutes in a sterile cabinet for adhesion and absorption of inocula. Then, the artificially cheese samples were dipped into the film which was contain $2 \%(\mathrm{v} / \mathrm{v}) \mathrm{EO}_{\mathrm{CVV}}$. The prepared samples were stored at $4 \pm 1{ }^{\circ} \mathrm{C}$ for 30 days and E. coli O157: H7, L. monocytogenes and S. aureus counts were calculated in terms of $\log _{10} \mathrm{cfu} / \mathrm{g}$ on the $1 \mathrm{st}, 7 \mathrm{th}, 15 \mathrm{th}$ and 30 th days of storage.

\subsection{Physical - chemical analysis}

Weight loss percentages of kashar cheese samples during storage were determined gravimetrically. $\mathrm{pH}$ values were examined with a SS-3 Zeromatic $\mathrm{pH}$ meter (Beckman Instruments Inc., California, USA). Acidity ( $\left.{ }^{\circ} \mathrm{SH}\right)$ and fat content (\%) were analyzed according to AOAC (Association of Official Analytical Chemists,2000). The inner-outer hardness was determined at $3 \pm 1{ }^{\circ} \mathrm{C}$ with a penetrometer (4500 CT3 texture analyzer Brookfield Made in USA). Film thicknesses were measured with a micrometer at 0.005 precision (Digimatic Micrometer/Japan). Water vapor permeability (WVP) of films was determined using ASTM E96-80 (American Society for Testing and Material, 1983) method gravimetrically at $25^{\circ} \mathrm{C}$. WVP was calculated by finding the slope of weight-time line and substituting it in the following formula (Equation 1).
$W V P=c \frac{x}{A \times \Delta p}$

A: Surface area $\left(\mathrm{m}^{2}\right)$

WVP: Water vapor permeability $\left(\mathrm{g} \mathrm{mm} \mathrm{m}^{-2} \mathrm{~h}^{-1} \mathrm{kPa}^{-1}\right)$

$\Delta \mathrm{p}$ : Partial pressure difference of the gases $(\mathrm{kPa})$

$\mathrm{x}$ : Coating thickness $(\mathrm{mm})$

\subsection{Microbiological analysis}

E.coli O157:H7 was enriched in selective modified EC Broth at $35-37^{\circ} \mathrm{C}$ 'de for $24-48$ hours. For enumeration of E.coli O157:H7 was used Sorbitol MacConkey Agar containing Cefixime-Tellurite Supplement and incubating at $35-37^{\circ} \mathrm{C}$ for 24-48 hours. After incubation, sorbitol negative colonies were counted. L. monocytogenes was enriched in Listeria selective Enrichment Broth at $30{ }^{\circ} \mathrm{C}$ for 24 hours. For enumeration of L. monocytogenes, Palcam Listeria Selective Agar (Base) was inoculeted and incubating at $37^{\circ} \mathrm{C}$ for 48 hours. S.aureus was enriched in Brain Hearth Infusion Broth at $37^{\circ} \mathrm{C}$ for 48 hours. \% 5 Egg Yolk Tellurite emulsion was added to Baird Parker Agar and incubating under aerobic conditions at $35-37^{\circ} \mathrm{C}$ for 24-48 hours. Than, colonies were counted (Food and Drug Administration, 2001).

\subsection{Statistical evaluation}

Five different cheese samples were examined with 3 parallels and 2 repetitions. For this purpose, SPPS version 15 statistical analysis package software was used. Data significance as a result of analysis of variance (ANOVA) were tested according to the Duncan multiple comparison test at $\mathrm{p}<0.05$ level.

\section{Results and discussion}

The film was divided into 3 equal parts; 1 part was coated edible film only EWPP, 2 part was contain $2 \%(\mathrm{v} / \mathrm{v}) \mathrm{EO}_{\mathrm{CVv}}$ $\left(\mathrm{EWPP}_{\mathrm{CVV}}\right)$, and the third part $(\mathrm{K})$ was applied to artificial contamination which was uncoated edible film (Figure 1).

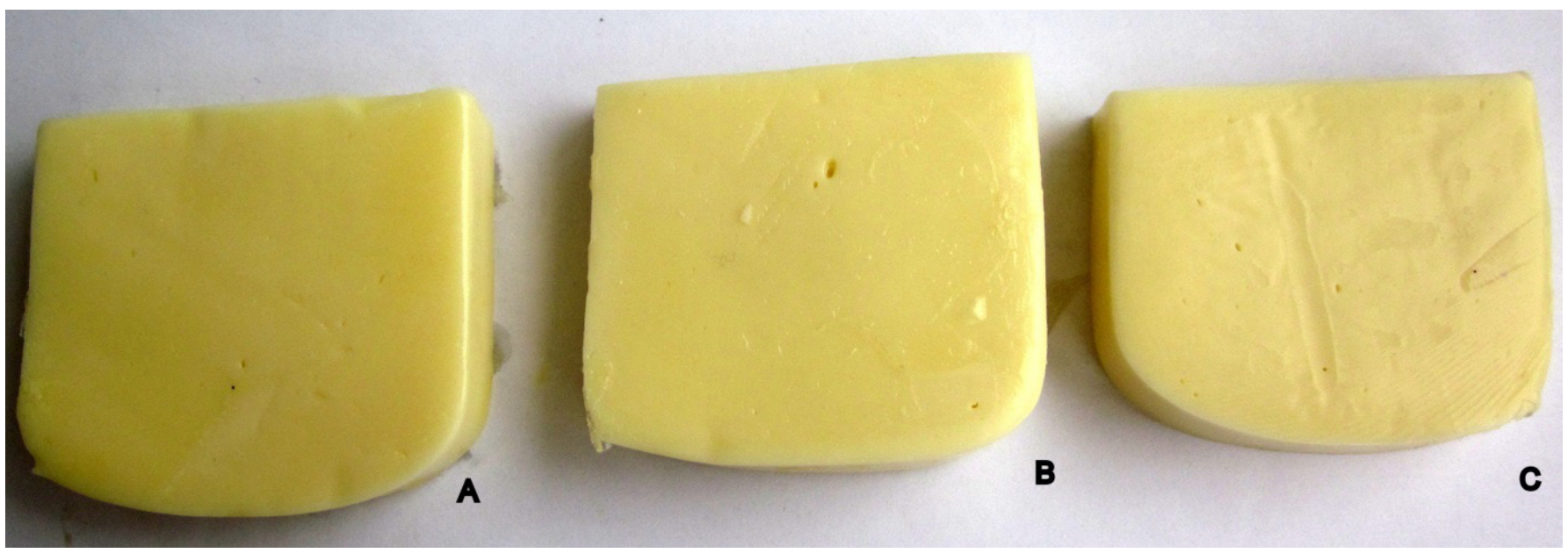

Figure 1. (A) coated kashar cheese with $\mathrm{EWPP}_{\mathrm{CVV}}$; (B) coated kashar cheese with EWPP; (C) uncoated kashar cheese (K) samples. 
The active substances of the CVV ( $\mathrm{pH}$ value 3.13 ) containing; limonen $84,2 \%$, sabinen $3.2 \%$, myrecene $1.2 \%$, $\beta$-pinene $1.3 \%$, a-pinene $0.47 \%$, linalol 3.54\%, $\alpha$-terpineol $1.14 \%$ and geranyl acetate $1.05 \%$ was obtained from $C$. sinensis $\mathrm{L}$. (Osbeck) var. valencia species.

The thickness of EWPP based film was $0.183 \mathrm{~mm}$ and the thickness of $2 \%(\mathrm{v} / \mathrm{v}) \mathrm{EO}_{\mathrm{CVV}}$ supplemented EWPP ${ }_{\mathrm{CVV}}$ was 0.185 $\mathrm{mm}$ (Table 1). The difference between the film thicknesses was not found to be significant ( $p>0.05$ ). Water vapor permeability was higher in samples coated with EWPP based film than in those coated with EWPP ${ }_{\mathrm{CVV}}$ based film; however this difference was not statistically significant ( $\mathrm{p}>0.05)$.

As seen in Table 2, the inner and outer hardness values during storage of the samples coated with $\mathrm{EWPP}_{\mathrm{CVV}}$ were lower than of those coated with EWPP. The differences observed between coated and uncoated $(\mathrm{K})$ cheese samples during storage were statistically significant in terms of inner and outer hardness values $(\mathrm{p}<0.05)$. Hardness values determined for the control were higher than those determined for film coated samples. In terms of storage days, the difference between the weight losses of the samples were not significant $(p>0.05)$. During storage, the weight losses of samples coated with $\mathrm{EWPP}_{\mathrm{CVV}}$ were lower than those coated with EWPP. Also, the weight loss differences between the coated and the non-coated $(\mathrm{K})$ samples were significant $(\mathrm{p}<0.05)$. A significant relationship was detected between weight loss and inner-outer hardness $(\mathrm{p}<0.05)$.

Protein based films have been characterized by their low water barrier properties in previous studies. Sarioğlu \& Oner (2006) reported that film coating caused a decrease in the inner and outer hardness (shell formation) of cheese samples. Additionally, in many studies, it has been reported that film coating prevented water vapor transmission and decreased weight losses (Krochta, 1997; Sarioğlu \& Oner 2006), also using protein based film together with lipids was effective in the prevention of weight losses in the product due to the high water vapor permeability of protein based films (Koyuncu \& Savran, 2002).

Table 1. Thicknesses and water vapor permeability of Ewpp and Ewpp $_{\mathrm{cvv}}$ based films.

\begin{tabular}{lcc}
\hline Samples & $\begin{array}{c}\text { Thickness } \\
/ \mathbf{m m} \pm \mathbf{6}\end{array}$ & $\begin{array}{c}\text { Water vapor } \\
\text { permeability } \\
\left(\mathbf{g ~ m m ~ m}^{-2} \mathbf{~ h}^{-1} \mathbf{~ k P a}^{-1}\right)\end{array}$ \\
\hline EWPP & $0.183 \pm 0.009$ & 7.78 \\
EWPP $_{\mathrm{CVV}}$ & $0.185 \pm 0.011$ & 7.71 \\
\hline
\end{tabular}

During storage, an increase in titratable acidity values ( $\left.{ }^{\circ} \mathrm{SH}\right)$ (decrease in $\mathrm{pH}$ values) in all samples of observed. The average $\mathrm{pH}$ decrease in the EWPP ${ }_{\mathrm{CVV}}$ coated samples $(5.21 \mathrm{pH})$ was higher than those in the control group $(5.26 \mathrm{pH})$ and EWPP $(5.27 \mathrm{pH})$. However, the $\mathrm{pH}$ decrease in the control sample on the 7 th day of the storage $(5.23 \mathrm{pH})$ was higher than those in EWPP $(5.26 \mathrm{pH})$ and EWPP $\mathrm{EvV}(5.20 \mathrm{pH})$. The $\mathrm{pH}$ decrease in the control sample continued to the end of the storage, reaching 4.93 by the 30 th day. The average $\mathrm{pH}$ values in EWPP and $\mathrm{EWPP}_{\mathrm{CVV}}$ samples did not change by the 15 th or the 30 th days of storage. The relationship between $\mathrm{EO}_{\mathrm{CvV}}$ addition and the acidity on the 1 st day was found significant $(\mathrm{p}<0.05)$. Also, the differences between the average $\mathrm{pH}$ values between EWPP $_{\mathrm{CVV}}$ and controls and between EWPP ${ }_{\mathrm{CVV}}$ and EWPP were significant $(\mathrm{p}<0.05)$, while the difference between the average $\mathrm{pH}$ values of control samples and EWPP was not significant $(\mathrm{p}>0.05)$. This was associated with the high acidity found in $\mathrm{EO}_{\mathrm{CVV}}$ (pH 3.13). A significant relationship was found between the storage period and the increase in acidity controls samples $(\mathrm{p}<0.05)$. This was possibly a result of the microbial growth that occurred in control samples during storage.

With $\mathrm{EO}_{\mathrm{CVV}}$ addition to EWPP based film, fat levels increased on the 1st days of the storage and the average fat values of $\mathrm{EWPP}_{\mathrm{CVV}}$ were higher than those of other samples during storage. The relationship between $\mathrm{EO}_{\mathrm{CVV}}$ addition and fat levels was significant $(\mathrm{p}<0.05)$. No significant changes in fat values were found in coated samples during storage; the decrease in fat value of the control was not significant. On the contrary, the relationship between $\mathrm{EO}_{\mathrm{CVV}}$ addition and fat levels was significant $(\mathrm{p}<0.05)$. Our study results are compatible with previous studies which have reported that composite films with good mechanical, fat, oxygen and water vapor barrier properties can be produced with addition of different essential oils to protein based films (Avena- Bustillos \& Krochta, 1993; Shellhammer \& Krochta, 1997) and also with the studies reporting that EWP based films show similar properties to other protein based films (Yuno-Ohta et al., 1996).

In our study, cheese samples were artificially contaminated with pathogenic microorganisms at $10^{6} \log 10 \mathrm{cfu} / \mathrm{g}(6 \mathrm{Log} 10 \mathrm{cfu} / \mathrm{g})$. It was determined that coating the cheese samples with film obtained by adding $2 \%(\mathrm{v} / \mathrm{v}) \mathrm{EO}_{\mathrm{CVV}}$ to EWPP based film had a bacteriostatic effect at storage period. In this study, antimicrobial activity observed in EWPP coated samples increased significantly with the addition of $2 \%(\mathrm{v} / \mathrm{v}) \mathrm{EO}_{\mathrm{CVV}}$ (Figure 2). Therefore, significant relationships were determined between coating the

Table 2. The average weight loss (\%) and inner-outer hardness values of EWPP and EWPP coated and non-coated control samples and their standard deviations $(\mathrm{p}<0.05),(\mathrm{n}=3)$.

\begin{tabular}{|c|c|c|c|}
\hline \multirow{2}{*}{ Day } & Outer hardness & Inner hardness & Weight losses (\%) \\
\hline & $\mathrm{K} \pm \sigma \mathrm{EWPP} \mathrm{CVV} \pm \sigma \mathrm{EWPP} \pm \sigma$ & $\mathrm{K} \pm \sigma \mathrm{EWPP} \mathrm{CVV} \pm \sigma \mathrm{EWPP} \pm 6$ & $\mathrm{~K} \pm \sigma \mathrm{EWPP} \mathrm{CVV} \pm \sigma \mathrm{EWPP} \pm \sigma$ \\
\hline 1 & $36.21 \pm 0.34^{\mathrm{aA}} 23.22 \pm 1.38^{\mathrm{bA}} 28.05 \pm 1.38^{\mathrm{cA}}$ & $24.36 \pm 1.46^{\mathrm{aA}} 22.32 \pm 1.16^{\mathrm{bA}} 25.22 \pm 1.45^{\mathrm{cA}}$ & $-\cdots$ \\
\hline 7 & $67.30 \pm 1.67^{\mathrm{aB}} 49.31 \pm 1.12^{\mathrm{bB}} 56.32 \pm 1.14^{\mathrm{cB}}$ & $35.11 \pm 1.73^{\mathrm{aB}} 26.26 \pm 1.11^{\mathrm{bA}} 28.84 \pm 2.85^{\mathrm{cA}}$ & $8.89 \pm 0.24^{\mathrm{a}} 7.73 \pm 0.49^{\mathrm{b}} 8.37 \pm 0.17^{\mathrm{c}}$ \\
\hline 15 & $83.68 \pm 2.11^{\mathrm{aB}} 62.51 \pm 1.11^{\mathrm{bC}} 75.11 \pm 1.36^{\mathrm{cC}}$ & $39.41 \pm 2.56^{\mathrm{aB}} 33.05 \pm 1.26^{\mathrm{bB}} 36.31 \pm 2.78^{\mathrm{cB}}$ & $7.65 \pm 0.11^{\mathrm{a}} 6.09 \pm 0.41^{\mathrm{b}} 6.75 \pm 0.05^{\mathrm{c}}$ \\
\hline 30 & $155.23 \pm 8.35^{\mathrm{aC}} 114.32 \pm 9.24^{\mathrm{bD}} 123.23 \pm 9.38^{\mathrm{cD}}$ & $94.56 \pm 1.28^{\mathrm{aC}} 49.45 \pm 0.36^{\mathrm{bC}} 55.34 \pm 4.29^{\mathrm{cC}}$ & $2.41 \pm 0.01^{\mathrm{a}} 1.35 \pm 0.02^{\mathrm{b}} 2.12 \pm 0.03^{\mathrm{c}}$ \\
\hline
\end{tabular}

6: Standard deviation $(\mathrm{n}=3)$; ${ }^{\mathrm{a}, \mathrm{b}, \mathrm{C}}$ : The differences between the values in the same line are statistically significant $(\mathrm{p}<0.05) ; \mathrm{A}, \mathrm{B}, \mathrm{C,D}$ : The differences between the values in the same column are statistically significant $(\mathrm{p}<0.05)$. 


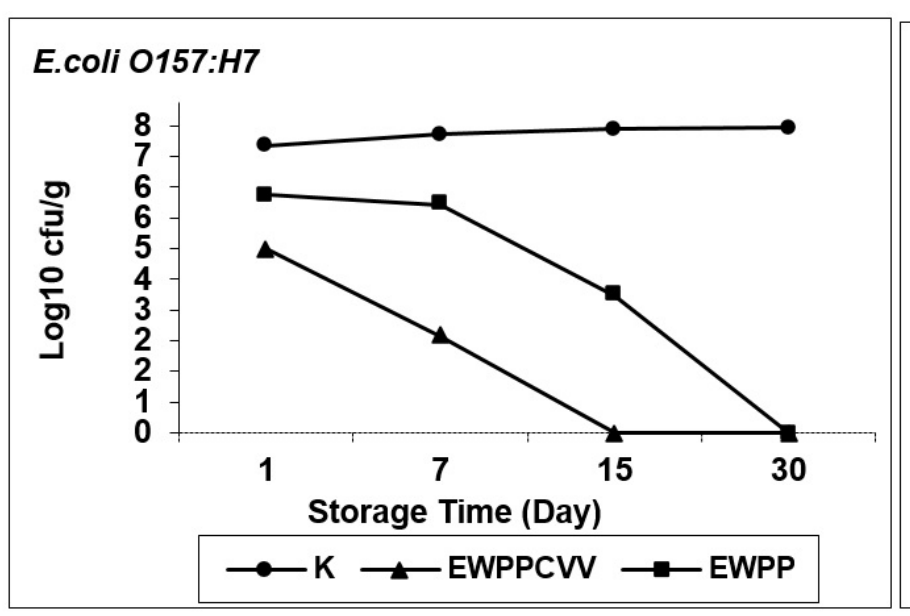

A

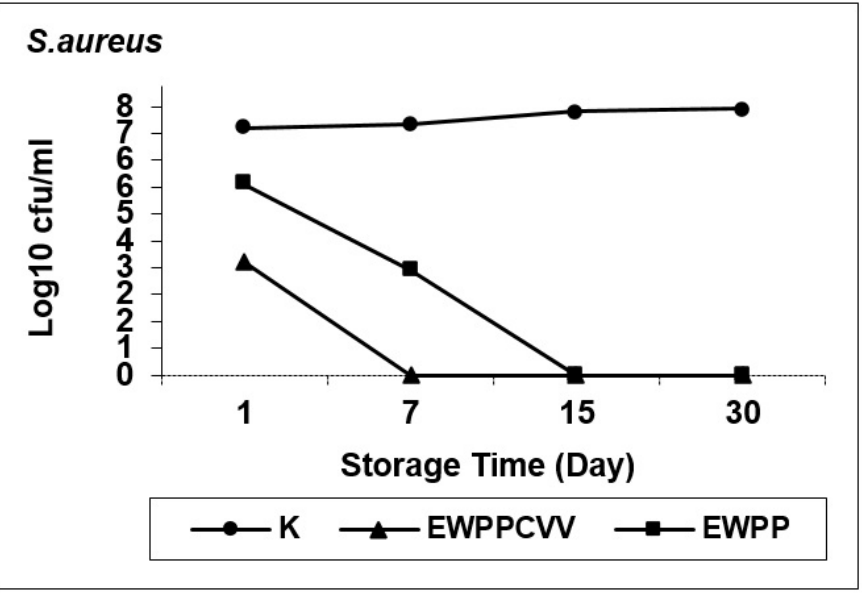

B

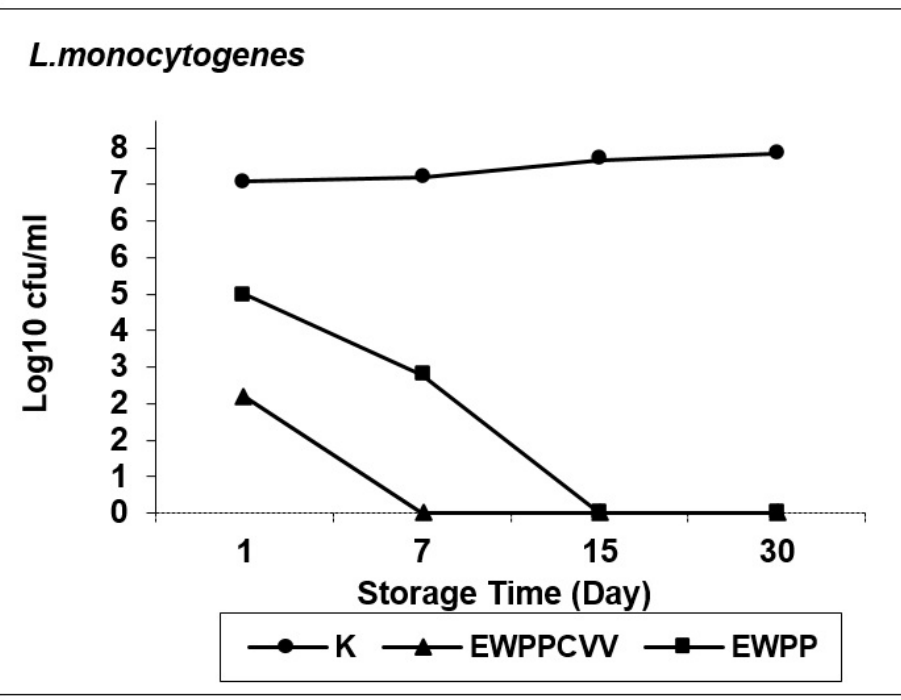

C

Figure 2. E. coli O157:H7. (A) S. aureus (B) and L. monocytogenes (C) growth in samples coated with film and K sample.

cheeses with EWPP based film and the antimicrobial activity and also between the increase in the antimicrobial activity and the addition of $\mathrm{EO}_{\mathrm{CVV}}$ to the film $(\mathrm{p}<0.05)$. The relationship between the antimicrobial effect and the progression of the storage period was also significant $(\mathrm{p}<0.05)$.

This result was associated with slower transmission of antimicrobial agent from the film layer to food in the edible film systems, with a high concentration of antimicrobial agent remaining in the film and the surface of the food, thus providing a longer effect against microorganisms (Coma et al., 2002). Also, in relation with the $\mathrm{pH}$ decrease in cheese samples, the increase in hydrophobicity of essential oil and the easier dissolution of cell membrane in the lipid phase have an effect on the increase in antimicrobial activity (Holley \& Patel, 2005). Additionally, it was concluded that limonene (84.2\%) and linalol (\% 3.54) which was found in high concentrations in the composition of $\mathrm{EO}_{\mathrm{CVV}}$ along with low concentrations of $\alpha$-pinenen $(0.47 \%)$, and the high acidity of $\mathrm{EO}_{\mathrm{CVV}}$ (pH 3.13) may have contributed to the increased antimicrobial activity. In previous studies, it has been found that limonene in the composition of $\mathrm{EO}_{\mathrm{CVV}}$ has antifungal properties and that limonene, $\alpha$-pinene and linalool have strong antimicrobial effects (Wilkins et al., 2007). The results regarding the antimicrobial activity of $\mathrm{EO}_{\mathrm{CVV}}$ in our study are compatible with other studies on different orange cultivars (Fisher \& Phillips, 2006; Pengelly, 2004; Rahman et al., 2010; Subba et al., 2006; Tepe et al., 2005). Also, it was also determined that the antimicrobial effects of EWP in foods reported in previous studies also apply to EWPP based edible films; using $\mathrm{EWPP}+\mathrm{EO}_{\mathrm{CVV}}$ together increased this effect.

In this study Microbial growth was highest in control samples throughout the storage. The antimicrobial effect of EWPP ${ }_{\mathrm{CVV}}$ coating was higher compared to EWPP coating. This effect increased in the later days of the storage. In fact, the decrease in E. coli O157:H7 levels in $\mathrm{EWPP}_{\mathrm{CVV}}$ samples on the 1st day of 
the storage was higher than was observed in EWPP. With the increase in antimicrobial effect in $\mathrm{EWPP}_{\mathrm{CVV}}$ between the 1st and the 7th days, the decrease in E. coli O157:H7 advanced (Figure 2A). Similar results were determined for S. aureus (Figure 2B) and L. monocytogenes (Figure 2C). On the 1st day of the storage, the antimicrobial effect of $\mathrm{EWPP}_{\mathrm{CVV}}$ for $S$. aureus (3.35 $\log _{10} \mathrm{cfu} / \mathrm{g}$ ) and L. monocytogenes (2.56 $\log _{10} \mathrm{cfu} / \mathrm{g}$ ) was higher than that of EWPP. The most sensitive microorganism to EWPP and $\mathrm{EWPP}_{\mathrm{CVV}}$ coating throughout the storage was S. aureus. Actually, S. aureus levels were lower than those of E. coli O157:H7and L. monocytogenes on all days of the storage in both of the coatings. It was concluded that with the addition of $2 \%(\mathrm{v} / \mathrm{v}) \mathrm{EO}_{\mathrm{CVV}}$ to EWPP based film, the antimicrobial effect was observed from the first days of the storage.

In this study, cheese samples coated with EWPP and EWPP $\mathrm{CVV}_{\mathrm{C}}$ prepared by addition of $2 \%(\mathrm{v} / \mathrm{v}) \mathrm{EO}_{\mathrm{CVV}}$ were evaluated in terms of color, structure, brightness and odor. In the evaluations, it was found that EWPP based film was brighter and more transparent compared to $\mathrm{EWPP}_{\mathrm{CVV}}$ based film and that $\mathrm{EWPP}_{\mathrm{CVV}}$ based film had a more yellowish color (Figure 1). Appearance criteria for the EWPP based film was compatible with the study by Gennadios et al. (1998) on the determination of properties of egg albumin based films. Additionally, a cooked egg smell was perceived in samples coated with EWPP based films. However, no such smell was detected in the case of $\mathrm{EWPP}_{\mathrm{CVv}}$; on the contrary, an orange scent was perceived and was well appreciated.

\section{Conclusion}

In our study, it was determined that EWPP based film was a good water and fat barrier. With the addition of $2 \%(\mathrm{v} / \mathrm{v})$ $\mathrm{EO}_{\mathrm{CVV}}$ to EWPP based film, the mentioned properties improved along with an increase in antimicrobial activity. Consequently, EWPP $_{\mathrm{CVV}}$ was more effective in the extension of the storage period compared to EWPP. The incorporation of essential oils into Egg White Protein Powder based edible film applied onto kashar cheese helps to reduce microbial load during 30 days of storage. These results support also the hypothesis that the inhibition of E. coli O157:H7, L. monocytogenes and S. aureus growth by essential oils depends on the nature of the phenolic compounds. The phenolic compound concentration could also play an important role in the antimicrobial activities that they confer to essential oils used in this study. Physically, the appearance of EWPP based film was found to be brighter and more transparent than $\mathrm{EWPP}_{\mathrm{CVV}}$ and therefore was more preferred, although $\mathrm{EWPP}_{\mathrm{CVV}}$ was preferred in terms of odor. $\mathrm{EWPP}_{\mathrm{CVV}}$ offer the potential for all natural antimicrobials for use in improving the safety of organic or all natural foods.

\section{References}

Abeyrathne, E. D. N. S., Lee, H. Y., \& Ahn, D. U. (2013). Egg white proteins and their potential use in food processing or as nutraceutical and pharmaceutical agents -- a review. Poultry Science, 92(12), 32923299. PMid:24235241. http://dx.doi.org/10.3382/ps.2013-03391.

American Society for Testing and Material - ASTM. (1983). E96-80: standard test methods for water vapor transmission of materials: annual book of American Standard Testing Methods (pp. 761-770). Philadelphia: ASTM.
Association of Official Analytical Chemists - AOAC. (2000). Official methods of analysis of the Association of Official Analytical Chemists International (1018 p). Washington: AOAC.

Avena-Bustillos, R. J., \& Krochta, J. M. (1993). Water vapor permeability of caseinate-based edible films as affected by $\mathrm{pH}$, calcium crosslinking and lipid content. Journal of Food Science, 58(4), 904-907. http:// dx.doi.org/10.1111/j.1365-2621.1993.tb09388.x.

Banwart, G. J. (1983). Basic food microbiology. Wcstport: AVI Pub Comp., Inc.

Belletti, N., Ndagijimana, M., Sisto, C., Guerzoni, M. E., Lanciotti, R., \& Gardini, F. (2004). Evaluation of the antimicrobial activity of citrus essences on Saccharomyces cerevisiae. Journal of Agricultural and Food Chemistry, 52(23), 6932-6938. PMid:15537299. http://dx.doi. org/10.1021/jf049444v.

Bounatirou, S., Smiti, S., Miguel, M. G., Faleiro, L., Rejeb, M. N., Neffati, M., Costa, M. M., Figueiredo, A. C., Barroso, J. G., \& Pedro, L. G. (2007). Chemical composition, antioxidant and antimicrobial activities of the essential oils isolated from Tunisian Thymus capitus Hoff. et Link. Food Chemistry, 105(1), 146-155. http://dx.doi.org/10.1016/j. foodchem.2007.03.059.

Bourtoom, T. (2008). Edible films and coatings: characteristics and properties. International Food Research Journal, 15(3), 237-248.

Burt, S. (2004). Essential oils their antibacterial properties and potential applications in foods-a review. International Journal of Food Microbiology, 94(3), 223-253. PMid:15246235. http://dx.doi. org/10.1016/j.ijfoodmicro.2004.03.022.

Coma, V., Martial-Gros, A., Garreau, S., Copınet, A., Salın, F., \& Deschamps, A. (2002). Edible antimicrobial films based on chitosan matrix. Journal of Food Science, 67(3), 1162-1169. http://dx.doi. org/10.1111/j.1365-2621.2002.tb09470.x.

Durlu-Ozkaya, F., \& Gün, I. (2007). Traditional Turkish Cheeses. In Proceedings of the International Symposium on Historical Cheeses of Countries around the Archipelago Mediterraneo, Thessaloniki, Greece.

Fisher, K., \& Phillips, C. A. (2006). The effect of lemon, orange, and bergamot essential oils and their components on the survival of Campylobacter jejuni, Escherichia coli O157, Listeria monocytogenes, Bacillus cereus and Staphylococcus aureus in vitro and in food systems. Journal of Applied Microbiology, 101(6), 1232-1240. PMid:17105553. http://dx.doi.org/10.1111/j.1365-2672.2006.03035.x.

Food and Drug Administration - FDA. (2001). Bacteriological analytical: manual online. New Hampshire: FDA. Retrieved from www.fda.gov

Gennadios, A., Rhim, J. V., Handa, A., Weller, C. L. \& Hana, M. A. (1998). Ultraviolet radiation affects physical and molecular properties of soy protein films. Journal of Food Science, 63, 225-228.

Gupta, M., Gularia, P., Singh, D., \& Gupta, S. (2014). Analysis of aroma active constituents, antioxidant and antimicrobial activity of C. sinensis, Citrus limetta and C. limon fruit peel oil by GC-MS. Biosciences Biotechnology Research Asia, 11(2), 895-899. http:// dx.doi.org/10.13005/bbra/1355.

Hamdan, D. I., Mohamed, M. E., Abdullah, R. H., Mohamed, S. M., \& El-Shazly, A. M. (2013). Anti-inflammatory, insecticidal and antimicrobial activities and chemical composition of the essential oils of different plant organs from navel orange (Citrus sinensis (L.) Osbeck var. Malesy) grown in Egypt. Journal of Medicinal Plants Research, 7(18), 1204-1215.

Holley, R. A., \& Patel, D. (2005). Improvement in shelf-life and safety of perishable foods by plant essential oils and smoke antimicrobials. Food Microbiology, 22(4), 273-292. http://dx.doi.org/10.1016/j. fm.2004.08.006. 
Kim, J., Marshall, M. R., \& Wei, C. I. (1995a). Antibacterial activity of some essential oil components against five foodborne pathogens. Journal of Agricultural and Food Chemistry, 46, 1739-1745.

Kim, J. M., Marshall, M. R., Cornell, J. A., Preston, J. F. III., \& Wei, C. I. (1995b). Antibacterial activity of carvacrol, citral, and geraniol against Salmonella typhimurium on culture medium and on fish cubes. Journal of Food Science, 60(6), 1364-1374. http://dx.doi. org/10.1111/j.1365-2621.1995.tb04592.x.

Ko, K. Y., \& Ahn, D. U. (2008). An economic and simple purification procedure for the large scale production of ovotransferrin from egg white. Poultry Science, 87(7), 1441-1450. PMid:18577628. http:// dx.doi.org/10.3382/ps.2007-00434.

Kovacs-Nolan, J. K. N., Phillips, M., \& Mine, Y. (2005). Advances in the value of eggs and egg components for human health. Journal of Agricultural and Food Chemistry, 53(22), 8421-8431. PMid:16248532. http://dx.doi.org/10.1021/jf050964f.

Koyuncu, M. A., \& Savran, H. E. (2002). Edible coatings. Suleyman Demirel University. Journal of the Institue of Science and Technology., 6(3), 73-83.

Krochta, J. M. (1997). Edible protein films and coatings. In S. Damodaran \& A. Paraf (Eds.), Food proteins and their applications (pp. 529-549). New York: Marcel Dekker.

Ladaniya, M. S. (2008). Citrus fruit biology, technology and evaluation (pp. 1-11). London: Academic Press.

Masters, K. (1991). Spray drying handbook (pp. 51-52). Harlow: Longman Scientific \& Technical.

Mchugh, T. H., \& Krochta, J. M. (1994). Milk protein based edible films and coatings. Food Tecnologie, 48(1), 97-103.

Padgett, T., Han, I. Y., \& Dawson, L. (1998). Incorporation of foodgrade antimicrobial compounds into biodegradable packaging films. Journal of Food Protection, 61(10), 1330-1335. PMid:9798150.

Pengelly, A. (2004). The constituents of medicinal plants: an introduction to the chemistry and therapeutics of herbal medicines (2nd ed., pp. 1-12, 25, 78, 101). Cambridge: CABI Publishing.

Pintado, C. M. B. S., Ferreira, M. A. S. S., \& Sousa, I. (2010). Control of pathogenic and spoilage microorganisms from cheese surface by whey protein films containing malic acid, nisin and natamycin. Food Control, 21(3), 240-246. http://dx.doi.org/10.1016/j.foodcont.2009.05.017.

Rahman, S., Parvez, A. K., Islam, R., \& Khan, M. H. (2010). Antibacterial activity of natural spices on multi drug resistant escherichia coli isolated from drinking water Bangladesh. Annals of Clinical Microbiology and Antimicrobials, 10(1), 10. PMid:21406097. http:// dx.doi.org/10.1186/1476-0711-10-10.

Ressouany, M., Vachon, C., \& Lacroix, M. (1998). Irradiation dose and calcium effect on the mechanical properties of cross-linked caseinate films. Journal of Agricultural and Food Chemistry, 46(4), 1618-1623. http://dx.doi.org/10.1021/jf970805z.

Sarioğlu, T., \& Oner, Z. (2006). Usage possibilities of an edible film for coating of kashar cheese and its effects on cheese quality. Journal of Food, 31(1), 3-10.

Shellhammer, T. H., \& Krochta, J. M. (1997). Whey protein emulsion film performance as affected by lipid type and amount. Journal of Food Science, 62, 390-394. http://dx.doi.org/10.1111/j.1365-2621.1997. tb04008.x.

Subba, M. S., Somithrı, T. C., \& Suryanarayana, R. A. O. (2006). Antimicrobial action of citrus oil. Journal of Food Science, 32(2), 225-227. http://dx.doi.org/10.1111/j.1365-2621.1967.tb01299.x.

Taqi, A., Aksar, K. A., Nagy, K., Mutıhac, L., \& Stamatın, I. (2011). Effect of different concentrations of olive oil and oleic acid on the mechanical properties of albumen (egg white) edible films. African Journal of Biotechnology, 10(60), 12963-12972. http://dx.doi. org/10.5897/AJB11.1971.

Tepe, B., Daferera, D., Sokmen, A., Sokmen, M., \& Polıssıou, M. (2005). Antimicrobial and antioxidant activities of the essential oils and various extracts of Salvia tomentosa Miller (Lamiaceae). Food Chemistry, 90(3), 333-340. http://dx.doi.org/10.1016/j.foodchem.2003.09.013.

Ucuncu, M. (2004). Cheese technology from A to Z. Bornova: Meta Basım.

Wilkins, M. R., Suryawat1, L., Maness, N. O., \& Chrz, D. (2007). Ethanol production by Saccharomyces cerevisiae and Kluyveromyces marxianus in the presence of orange-peel oil. World Journal of Microbiology \& Biotechnology, 23(8), 1161-1168. http://dx.doi.org/10.1007/ s11274-007-9346-2.

Yuno-Ohta, N., Toryu, H., Higasa, T., Maeda, H., Okada, M., \& Ohta, H. (1996). Gelation properties of ovalbumin as affected by fatty acid salts. Journal of Food Science, 61(5), 906-910. http://dx.doi. org/10.1111/j.1365-2621.1996.tb10899.x.

Zivanovic, Z., Chi, S., \& Draughon, A. F. (2005). Antimicrobial activity of chitosan films enriched with essential oils. Journal of Food Science, 70(1), 45-51. http://dx.doi.org/10.1111/j.1365-2621.2005.tb09045.x. 